\title{
Relationship Between Climate Change and Tropical Disease in Poor Coastal Area, Serdang Bedagai
}

\author{
Destanul Aulia ${ }^{1}$, Sri Fajar Ayu ${ }^{2}$ \\ ${ }^{1}$ Department of Health Policy and Administration, University of Sumatera Utara, Indonesia \\ destanul.aulia@usu.ac.id \\ ${ }^{2}$ Department of Agribusiness, University of Sumatera Utara, Indonesia
}

ayu_srifajareyahoo.com

\begin{abstract}
The climate change in Indonesia has affected the fishing activity of fisheries in Indonesia, because the activity of fisheries is strongly influenced by climate change. The change in climate in Indonesia led to changes within the pattern of wind speed, current speed, precipitation, sea-surface temperature and wave height. This conditions will affect the income of the fishermen, who are among the poorest Indonesian. In addition to causing loss of income, climate change also threatens the health of this fishing community. In order to understand the community's perception about climate change and its affect on the spread of tropical disease and the relationship of both, this survey study conducted. The data gathered through the interviewed based questionnaire. The samples are 71 residents of coastal communities subdistrict Tanjung Beringin, District Serdang Bedagai, who previously suffering from tropical diseases (tuberculosis, malaria, dengue and diarrhea). The results of the study shows that most coastal communities within the study area understand climate changes have occurred in their area. They also understand that climate change will cause the development of tropical diseases, they have suffered. The correlation analysis also shows that there is a significant relationship between perceptions about climate change and tropical diseases. Finally this study suggest that the study area urgently need a health promotion effort, so that people in coastal areas can implement the "clean and healthy living behavior", program to avoid the outbreak of a tropical disease in this area
\end{abstract}

Keywords - climate change, poor coastal area, tropical disease, health promotion, clean and healthy living behavior

\section{INTRODUCTION}

The main impacts of climate change in Indonesia include increase temperature, intense rainfall and sea-level rise [11]. This situation will affect the income among the poor in Indonesia, including fishermen. This is because the fishing activity of fisheries in Indonesia is strongly influenced by climate change, which led to changes within the pattern of wind speed, current speed, precipitation, sea-surface temperature and wave height [1]-[3], [12]-[14].

In addition to causing loss of income, Indonesian fishermen who are poor in Indonesia, climate change also threatens the health of this fishing community.
Tuberculosis, for example, are very vulnerable to climate change [17]. Today, Indonesia is the country with the second largest number of TB patients around the world [19]. Temperatures risen by 1.0 $3.5^{\circ} \mathrm{C}$ will increase the likelihood of many vectorborne diseases such as Malaria and Dengue fever in the tropics area [6]. Rainfall, shifts in precipitation affects the dissemination of water-borne pathogens. Rainy season is related to the increase of fecal pathogens as heavy rain may stir up sediments inwater, leading to the accumulation of fecalmicroorganisms [7]. Many infectious diseases are transmitted by ingestion of, inhalation of, or contact with contaminated water [14]. These infections can also lead to a wide range of clinical illness such as diarrheal disease which is the second leading cause of death among children under the age of five worldwide [18].

Serdang Bedagai (Sergei) is one of the districts in the East Coast Region North Sumatra, Indonesia. The district has the advantage in the field of marine and agriculture. Based on the Health Profile of North Sumatera (2012) note that an outbreak of tropical diseases is still high in the district, such as Tuberculosis (772 cases), Malaria (90 cases), Dengue Fever (49 cases), and the symptoms of Diarrhea (25.550 cases). Serdang Bedagai has 17 sub-districts. One of the district is Tanjung Beringin with a population of 37,497 peoples (Central Bureau of Statistics District Sergei, 2015). Community of Tanjung Beringin mostly works as fishermen because this district is located along the coast. Tropical disease cases in the district of Tanjung Beringin is fairly high. According to Central Bureau of Statistics District Sergei (2015) Tanjung Beringin Sub-district has the case of Tuberculosis 
(20 cases), Malaria (4 cases), Dengue Fever (17 cases), and the symptoms of Diarrhea (632 cases).

Just like most other Indonesian fishing communities, fishermen in this area live in poverty [10]. Poverty comes not only in economics but also in the social, cultural and even political. In addition, poverty is not only within the scope of the family, but also within the scope of the village, which is manifested under the form of poverty infrastructure. The poverty among fishing communities alone has caused them difficulty gaining access to health services, coupled with the influence of climate change on the spreading of various tropical diseases, it will make their lives even worsen. Thus climate change is an issue that should be recognized and anticipated by Indonesian fishermen, as well as policy makers also need to make efforts to help the fishermen, so it is necessary to study the relationship of climate change and tropical diseases in poor areas along the coast.

\section{METHODOLOGY}

This study is a survey research using questionnaires. The questionnaires used for consist of two sections. The first section is about respondent's perception on climate change, and a second one is about the perceptions of tropical disease caused by climate change. Both using Likert scale with a scale of 1 to 4 , strongly disagree, disagree, agree and strongly agree.

The diseases studied are tuberculosis, malaria, dengue and diarrhea. This relates to Central Statistics Bureau Serdang Bedagai (2015) reports regarding the tropical diseases that develop in the sub-district of Tanjung Beringin. The number of cases and the number of respondents studied are presented in Table 1.

TABLE I

NUMBER OF CASES OF TROPICAL DISEASES IN THE DISTRICT OF TANJUNG BERINGIN AND THE NUMBER OF SAMPLES STUDIED

\begin{tabular}{|c|c|c|}
\hline $\begin{array}{c}\text { Tropical } \\
\text { Diseases }\end{array}$ & $\begin{array}{c}\text { Number of Cases } \\
\text { (BPS, 2015) }\end{array}$ & $\begin{array}{c}\text { Number of } \\
\text { Samples }\end{array}$ \\
\hline Tuberculosis & 20 & 20 \\
\hline Malaria & 4 & 4 \\
\hline Dengue & 17 & 17 \\
\hline Diarrhea & 632 & 30 \\
\hline Total & $\mathbf{6 7 3}$ & $\mathbf{7 1}$ \\
\hline
\end{tabular}

Respondents representing diarrhea diseases are only 30 peoples because in general the sample 30 is considered adequate for testing correlation [4]. Finally, the total samples used are 71 samples. The sampling process was done purposively based on data from the Public Health Centre Tanjung Beringin.

The collected data were analyzed descriptively to draw conclusions on the perceptions of respondents about climate change, and the tropical diseases caused by climate change. The relationship between perceptions of climate change and the spread of infectious diseases analyzed using Pearson's correlation analysis. The formula is as the following:

$$
r=\frac{\sum x y-\frac{\left(\sum x\right)\left(\sum y\right)}{n}}{\sqrt{\left(\sum x^{2}-\frac{\left(\sum x\right)^{2}}{n}\right)\left(\sum y^{2}-\frac{\left(\sum y\right)^{2}}{n}\right)}}
$$

\section{RESULT AND DISCUSSION}

Climate change in Indonesia is believed to have an impact as the development of tropical diseases, an increase in surface temperatures, changes in rainfall, changes in sea-surface temperature, sea level changes, as well as extreme weather and climate events. This situation will affect the people whose livelihoods depend on natural resources because it is more sensitive to environmental changes, such as fishermen. The opinions of the fishermen about climate change gathered and presented in Table 2.

TABLE II

RESPONDENT'S PERCEPTIONS ABOUT ClimATE CHANGE

\begin{tabular}{|c|l|c|c|c|c|}
\hline No & \multicolumn{1}{|c|}{ Statement } & $\begin{array}{l}\text { Strongly } \\
\text { Disagree }\end{array}$ & Disagree & Agree & $\begin{array}{c}\text { Strongly } \\
\text { Agree }\end{array}$ \\
\hline 1 & $\begin{array}{l}\text { Now, if the weather is } \\
\text { hot, its heat more blazing }\end{array}$ & 0 & 59 & 12 \\
\hline 2 & $\begin{array}{l}\text { Now, if the weather is hot, the heat } \\
\text { longer }\end{array}$ & 0 & 0 & 61 & 10 \\
\hline 3 & $\begin{array}{l}\text { Now if the weather is rainy, the rain is h } \\
\text { eavier than before. }\end{array}$ & 0 & 1 & 54 & 16 \\
\hline 4 & $\begin{array}{l}\text { The rainy season (Sept, October and } \\
\text { November) is the more dense, and dry } \\
\text { season (Jan, Feb. and Mar) drier } \\
\text { (extreme weather). }\end{array}$ & 0 & 3 & 60 & 8 \\
\hline 5 & $\begin{array}{l}\text { Seawater heat causes the fish often } \\
\text { move, makes it difficult to catch fish.. }\end{array}$ & 0 & 0 & 64 & 7 \\
\hline 6 & Sea level surface is expanding. & 0 & 0 & 60 & 11 \\
\hline 7 & $\begin{array}{l}\text { Lately droughts happen frequently, and } \\
\text { the droughts cause tropical disease. }\end{array}$ & 0 & 1 & 52 & 18 \\
\hline
\end{tabular}




\begin{tabular}{|c|l|c|c|c|c|}
\hline No & \multicolumn{1}{|c|}{ Statement } & $\begin{array}{l}\text { Strongly } \\
\text { Disagree }\end{array}$ & Disagree & Agree & $\begin{array}{c}\text { Strongly } \\
\text { Agree }\end{array}$ \\
\hline 8 & $\begin{array}{l}\text { There has been frequent flooding lately, } \\
\text { and flooding will spread infectious } \\
\text { disease. }\end{array}$ & 0 & 0 & 63 & 8 \\
\hline 9 & $\begin{array}{l}\text { Lower humidity causes the flu virus } \\
\text { spread more quickly. }\end{array}$ & 0 & 0 & 54 & 17 \\
\hline 10 & $\begin{array}{l}\text { Lately, the wind blowing harder, and it } \\
\text { can cause a whirlwind. }\end{array}$ & 0 & 0 & 49 & 22 \\
\hline & Total & & 5 & 576 & 129 \\
\hline Percentage & & 0.7 & 81.1 & 18.2 \\
\hline
\end{tabular}

Table 2 shows that most respondents chose to agree to the ten questions related to climate change $(81.1 \%)$. The respondent who chooses "strongly agree" is the second largest with a percentage of 18.2. The least respond is "disagreed," 0.7 percent of all answers. There is no "strongly disagree" respond from all the samples. Furthermore, the results from the "interviewed based questionnaire" to study the perceptions of tropical diseases related to climate change are presented in Table 3.

TABLE III

RESPONDENT'S PERCEPTION ABOUT TROPICAL DISEASES THAT CAUSED B Y Climate CHANGE

\begin{tabular}{|c|c|c|c|c|c|}
\hline No & Statement & $\begin{array}{l}\text { Strongly } \\
\text { Disagree }\end{array}$ & Disagree & Agree & \begin{tabular}{|c} 
Strongly \\
Agree
\end{tabular} \\
\hline 1 & $\begin{array}{l}\text { Malaria disease is increasing now, } \\
\text { because there are a lot of Anopheles } \\
\text { mosquitoes, due to the increasingly } \\
\text { hot weather. }\end{array}$ & 0 & 0 & 59 & 12 \\
\hline 2 & $\begin{array}{l}\text { At first, malaria occurs because the } \\
\text { Anopheles mosquito bites and there } \\
\text { has been a lot of Anopheles lately, } \\
\text { because of the higher temperatures }\end{array}$ & 0 & 0 & 61 & 10 \\
\hline 3 & $\begin{array}{l}\text { After being bitten by mosquitoes, } \\
\text { persistent fever, hot and cold } \\
\text { alternately, dizziness and sleepiness, } \\
\text { they are all the sign of malaria, the } \\
\text { symptom is now more common in } \\
\text { this village than in the past. }\end{array}$ & 0 & 1 & 54 & 16 \\
\hline 4 & $\begin{array}{l}\text { Heavy rain resulted in waterlogging, } \\
\text { causing dengue mosquito (Aedes) } \\
\text { develops rapidly. }\end{array}$ & 0 & 3 & 60 & 8 \\
\hline 5 & $\begin{array}{l}\text { The air is getting hot when it does not } \\
\text { rain, shortening the time required the } \\
\text { development of the egg phase into } \\
\text { adult mosquitoes. So there are a lot of } \\
\text { mosquitoes that cause dengue fever in } \\
\text { this village. }\end{array}$ & 0 & 0 & 64 & 7 \\
\hline 6 & $\begin{array}{l}\text { After being bitten by Aedes } \\
\text { mosquitoes, dengue fever occurs, } \\
\text { headache, pain in the bones and } \\
\text { muscles, nausea, vomiting, mild } \\
\text { cough and symptoms of bleeding also } \\
\text { happen. This is a symptom of dengue } \\
\text { fever, and it is more common now } \\
\text { than in the past. }\end{array}$ & 0 & 0 & 60 & 11 \\
\hline
\end{tabular}

\begin{tabular}{|c|l|c|c|c|c|}
\hline No & \multicolumn{1}{|c|}{ Statement } & $\begin{array}{l}\text { Strongly } \\
\text { Disagree }\end{array}$ & Disagree & Agree & $\begin{array}{c}\text { Strongly } \\
\text { Agree }\end{array}$ \\
\hline 7 & $\begin{array}{l}\text { Heavy rainfall often causes flooding, } \\
\text { and this condition led to the } \\
\text { widespread pollution of water } \\
\text { contaminated with feces. }\end{array}$ & 0 & 1 & 52 & 18 \\
\hline 8 & $\begin{array}{l}\text { The unhygienic water (contaminated } \\
\text { feces) continued to be used because } \\
\text { there is no other source of clean } \\
\text { water. }\end{array}$ & 0 & 0 & 63 & 8 \\
\hline 9 & $\begin{array}{l}\text { The use of contaminated water is } \\
\text { causing more people to become } \\
\text { stomachache (diarrhea) than in the } \\
\text { past. }\end{array}$ & 0 & 0 & 54 & 17 \\
\hline 10 & $\begin{array}{l}\text { The weather gets humid, lower } \\
\text { revenue due to difficulty to catch fish, } \\
\text { housing that does not meet the health } \\
\text { requirements, are all the causes of } \\
\text { many cases of tuberculosis in this } \\
\text { village. }\end{array}$ & 0 & 0 & 49 & 22 \\
\hline & Percentage & 0 & 5 & 576 & 129 \\
\hline
\end{tabular}

Table 3 shows that the majority of respondents chose to agree with the phenomena, they have seen that climate change is likely to lead to the spreading of tropical diseases. The process during the interview is not as easy as expected. There are a lot of respondents do not understand the effect of climate change in the spread of tropical diseases, but when the interviewer explained the processes that occur, most fishermen justify each proposed statement.

Having described the respondent's perception about climate change and tropical diseases that develop due to climate change, correlation analysis was also done to analyze the relationship between the two. Correlation analysis results are presented in Table 4.

TABLE IV

RESUltS OF CORRELATION ANALYSIS BETWEEN TROPICAL DISEASES AND PERCEPTION OF ClimATE CHANGE

\begin{tabular}{|ll|c|c|}
\hline \multicolumn{1}{|c|}{ Variabel } & Pearson Correlation & Sig. (2-tailed) \\
\hline 1. & $\begin{array}{l}\text { Perception about } \\
\text { Climate Change }\end{array}$ & $0,597^{* *}$ & 0,000 \\
2. Tropical disease & & \\
\hline
\end{tabular}

Based on the table it can be seen that there is a significant correlation between perceptions of climate change and the widespread tropical disease caused by climate change. However, the effect of climate change is can be lowered with clean and healthy living behavior. Fixing a clean and healthy life behavior (the program from the health ministry) under conditions of climate change has become a 
very important agenda in an effort to make the healthy community, especially to avoid these tropical disease outbreaks.

\section{IV.CONCLUSION}

1) Most coastal communities within the study area understand climate changes have occurred in their area.

2) Most coastal communities within the study area to understand that climate change will cause the development of tropical diseases, they have suffered .

3) There is a significant relationship between perceptions about climate change and tropical diseases.

\section{SUGGESTION}

The study area urgently need a health promotion effort, so that people in coastal areas can implement the "clean and healthy living behavior" program to avoid the outbreak of a tropical disease in this area.

\section{REFERENCES}

[1]. Brander, K. 2010. Impacts of climate change on fisheries. Journal of Marine Systems 79:389-402.

[2]. Daw, T.; Adger, W.N.; Brown, K.; Badjeck, M.-C. 2009. Climate change and capture fisheries: potential impacts, adaptation and mitigation. In K. Cochrane, C. De Young, D. Soto and T. Bahri (eds). Climate change implications for fisheries and aquaculture: overview of current scientific knowledge. FAO Fisheries and Aquaculture Technical Paper. No. 530: 107-150. Rome, FAO107-150.

[3]. Dedy Putra Wahyudi. 2010. Pola Adaptasi Nelayan Terhadap Perubahan Iklim Dan Cuaca Pada Perikanan Payang Di Palabuhanratu, Sukabumi, Jawa Barat. Thesis. Bogor, Institut Pertanian Bogor.

[4]. Diehl, L. R. and Gay, P. L. 1992. Research methods for business and management. New York: Macmillan Publishing.

[5]. Epstein, P. R., Diaz, H., Elias, S., Grabherr, G., Graham, N. E., Martens, W. J. M., Mosley-Thompson, E. And Susskind, J. 1998. Biological and physical signs of climate change: Focus on mosquito-borne diseases. Bulletin of the American Meteorological Society 79(3):409- 417.

[6]. Githeko, A. K., Lindsay, S. W., Confalonieri, U. E. \& Patz, J. A. 2000 Climate change and vector-borne diseases: A regional analysis. Bulletin of the World Health Organization 78(9):1136-1147.

[7]. Jofre, J., Blanch, A.R., Lucena, F., 2010.Water-borne infectious disease outbreaks associated with water scarcity and rainfall events. In: Sabater, S., Barcelo, D. (Eds.), Water Scarcity in the Mediterranean: Perspectives Under Global Change. Springer.

[8]. Kementrian PPN. 2014. Rencana Aksi Nasional Adaptasi Perubahan Iklim (RAN-API): Perubahan Iklim dan Dampaknya di Indonesia http://perpustakaan.bappenas.go.id/lontar/file?file=digital/153661\%5B Konten_\%5D-Konten\%20D492.pdf (Accsessed December 17, 2016).

[9]. Lafferty, K. D. 2009. The ecology of climate change and infectious diseases. Ecology 90(4): 888-900.

[10]. Masyhuri Imron. 2003. Kemiskinan dalam masyarakat nelayan. Jurnal Masyarakat dan Budaya 5(1):63-81.

[11]. Measey, M. 2010. Indonesia: A vulnerable country in the face of climate change. Global Majority E-Journal 1(1): 31-45. https://www.american.edu/cas/economics/ejournal/upload/global_majo rity_e_journal_1-1_measey.pdf

[12]. Nurlaili. 2012. Strategi adaptasi nelayan bajo menghadapi perubahan iklim: Studi nelayan Bajo Di Kabupaten Sikka, Flores, Nusa Tenggara Timur. Jurnal Masyarakat \& Budaya 14(3):599-624.
http://jmb-lipi.or.id/index.php/jmb/article/viewFile/107/88

[13]. Ratna Patriana and Arif Satria. 2013. Pola adaptasi nelayan terhadap perubahan iklim: Studi kasus nelayan Dusun Ciawitali, Desa Pamotan, Kecamatan Kalipucang, Kabupaten Ciamis, Jawa Barat. Jurnal Sosial Ekonomi Kelautan dan Perikanan 8(1):11-23. http://ejournalbalitbang.kkp.go.id/index.php/sosek/article/download/1191/1102

[14]. Shuman, E. K. 2010. Global Climate Change and Infectious Diseases. The New England Journal of Medicine 362:1061-1063. http://www.nejm.org/doi/full/10.1056/NEJMp0912931\#t=article56/NE JMp0912931.

[15]. Tito Aditya Perdana. 2015. Dampak Perubahan Iklim terhadap Nelayan Tangkap: Studi Empiris Di Pesisir Utara Kota Semarang. Thesis. Semarang: Universitas Diponegoro.

[16]. Trask, J. W. 1917. Climate and tuberculosis: The relation of climate to recovery. Public Health Reports 32(8):318-324.

[17]. World Health Organization. 2013. Diarrhoeal disease. http://www.who.int/mediacentre/factsheets/fs330/en/ (Accessed December 17, 2016).

[18]. World Health Organization. 2016. Media Centre: Tuberculosis, Fact sheet. http://www.who.int/mediacentre/factsheets/fs104/en/ . (Accessed December 17, 2016).

[19]. Xiaoxu W., Yongmei L., Sen Z., Lifan C., and Bing X. 2016. Impact of climate change on human infectious diseases: Empirical evidence and human adaptation. Environment International 86:14-23. 